\title{
COMPOSITION, PHYSICAL AND TECHNOLOGICAL PROPERTIES OF RAW MILK AS AFFECTED BY CATTLE BREED, SEASON AND TYPE OF DIET*
}

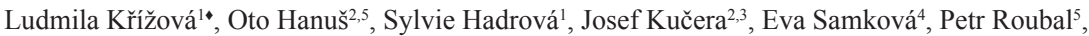 \\ Aleš Veselý ${ }^{1}$ \\ 'Department of Animal Nutrition and Quality of Livestock Products, Agrovyzkum Rapotín Ltd., \\ Výzkumníků 267, 78813 Vikýřovice, Czech Republic \\ ${ }^{2}$ Department of Laboratory, Research Institute for Cattle Breeding Ltd., Výzkumníků 267, \\ 78813 Vikýřovice, Czech Republic \\ ${ }^{3}$ Faculty of Agronomy, Mendel University in Brno, Zemědělská 1, 61300 Brno, Czech Republic \\ ${ }^{4}$ Faculty of Agriculture, University of South Bohemia České Budějovice, Studentská 13, \\ 37005 České Budějovice, Czech Republic \\ ${ }^{5}$ Dairy Research Institute, Ltd., Prague, Ke Dvoru 12a, 16000 Praha 6, Czech Republic \\ •Corresponding author: ludmila.krizova@vuchs.cz
}

\begin{abstract}
The aim of the study was to describe the differences in composition, physical and technological properties of raw milk as affected by breed of cattle, season and type of feeding. The study was conducted from June 2005 to February 2007 on bulk milk samples (BMS) collected from 8 commercial dairy herds consisting of Czech Fleckvieh (CF, 4 herds) and Holstein (H, 4 herds) dairy cows. Half of herds in each breed was grazing (G) during summer season while the other half was not $(\mathrm{N})$. Samples were collected regularly two times in winter (W) and two times in summer (S) period resulting in a total of 64 bulk milk samples (BMS) examined. Milk yield in CF (5385.50 kg) was lower $(\mathrm{P}<\mathbf{0 . 0 5})$ than in $\mathrm{H}(\mathbf{7 0 1 5 . 1 5} \mathrm{kg})$. Milk fat in $\mathrm{CF}$ was higher $(\mathrm{P}<0.05)$ than in $\mathrm{H}$ breed being 3.9 and $3.72 \mathrm{~g} / 100 \mathrm{~g}$, respectively. $\mathrm{CF}$ cows had higher $(\mathrm{P}<0.05)$ content of crude protein, casein, true protein and non-protein nitrogen (NPN) than H. Content of fat, crude protein, casein, true protein and whey protein was lower $(\mathbf{P}<0.05)$ in summer $(S)$ than in winter $(\mathrm{W})$. Milk yield in grazing herds $(G, 5197.50 \mathrm{~kg})$ was lower $(P<0.05)$ than in non-grazing herds $(\mathrm{N}, 7203.75 \mathrm{~kg})$. Content of fat was higher $(\mathrm{P}<0.05)$ in $\mathrm{G}(\mathbf{3 . 8 9} \mathrm{g} / \mathbf{1 0 0} \mathrm{g})$ than in $\mathrm{N}(3.73 \mathrm{~g} / 100 \mathrm{~g})$. Concentration of lactose, urea, crude protein, casein, true protein, whey protein was lower $(\mathrm{P}<0.05)$ in $\mathrm{G}$ than in $\mathrm{N}$. In conclusion, the Czech Fleckvieh breed had a lower milk yield but produced milk with higher concentration of the main milk components than the Czech population of the Holstein breed. Large seasonal variations were determined in concentrations of the main milk components. The most pronounced changes in milk composition were caused by the type of feeding with a clear decrease in milk yield and content of lactose and all studied protein fractions and higher content of fat in grazing herds compared to non-grazing herds.
\end{abstract}

Key words: cow genotype, Czech Fleckvieh, Holstein, bulk milk, pasture

*This study was supported by the Ministry of Education, Youth and Sports of the Czech Republic project KONTAKT No. ME09081 and the institutional support by decisions RO0313, RO0513 (both from 28 February 2013), project MSM 6215648905 and by project of Ministry of Agriculture No NAZV QH81105. 
Milk is a food with high nutritional benefits and it is, therefore, considered an important source of food for all age groups (Schönfeldt et al., 2012). It is well known that composition of raw bovine milk is determined by several factors such as breed, nutrition, season, stage of lactation, parity (Jensen, 2002) or herd management (Schennink et al., 2007). Furthermore, breed and farming systems of dairy cows differ significantly between countries resulting in differences in the composition and technological properties of milk (Schönfeldt et al., 2012). Also seasonal variations and regional (within country) differences in milk composition are of great importance to the manufacturers of dairy products as major influencing factors in the rennet coagulation properties of milk (Auldist et al., 2002) resulting in various retail practices with an economic impact. Recent studies that focused on the characterisation of country-specific compositional data for milk (Hanuš et al., 2007, 2011, 2012; Janů et al., 2007 a; Heck et al., 2009; Chládek et al., 2011; Kriščiunaite et al., 2012; Schönfeldt et al., 2012) highlighted the importance of such data not only for farmers and the dairy industry but also for consumers. The feeding regimen and breeding practices in dairy husbandry have changed a lot during the past decades in the Czech Republic (above all marked reduction of dairy population, changes in breed structure, improvement in cows' milk yield and nutrition, use of new technologies) resulting in changes of raw milk quality, especially hygienic and health indicators (Hanuš et al., 2007; Janů et al., 2007 a; Frelich and Šlachta, 2011). Furthermore, the opinions about milk as food were developed and there is an increasing demand for food safety and traceability of dairy products and also a demand for new dairy products; thus, up-to-date information concerning the raw bovine milk composition is essential. A detailed overview of the country-specific milk composition with regards to breed, nutritional and seasonal differences is also needed to set a standard to detect favourable or unfavourable changes in the future.

Thus, the aims of this study were to gain information on the current composition of Czech dairy milk and to analyse the effect of the two predominant breeds reared in the Czech Republic and the effects of season and feeding management on the nutritional and technological characteristics of raw bovine milk.

\section{Material and methods}

\section{Animals and design of the study}

The study was conducted from June 2005 to February 2007 on bulk milk samples (BMS) collected from 8 commercial dairy herds consisting of Czech Fleckvieh (CF, 4 herds) and Holstein (H, 4 herds) dairy cows. The average herd size was $185 \pm 149$ (from 66 to 439 ) dairy cows and the average milk yield was $6200.6 \pm 1455.1$ (from 3836 to 8124 ) $\mathrm{kg}$ (see Table 1 also for details about selected farm environmental characteristics). Cows were fed diets typical in the Czech Republic; based on maize silages, clover-grass haylages, hay, locally available feedstuffs, concentrate and mineral mixtures according to relevant milk yield (MY) and standard requirements. Half of herds in each breed was grazing $(G)$ during summer season while the 
other half was not $(\mathrm{N})$ as it is mentioned in Table 1. Cows were milked twice a day. Samples were collected regularly two times in winter (W, December and February) and two times in summer (S, June and August) period resulting in a total of 64 BMS examined.

Table 1. Experimental design and basic information about environment of dairy cow herds ${ }^{1}$

\begin{tabular}{l|c|c|c|c|c|c|c}
\hline $\begin{array}{c}\text { Farm } \\
\text { No. }\end{array}$ & Breed & $\mathrm{n}$ & $\begin{array}{c}\text { Type } \\
\text { of diet }\end{array}$ & $\begin{array}{c}\text { Milk yield } \\
(\mathrm{kg})\end{array}$ & $\begin{array}{c}\text { Altitude } \\
(\mathrm{m})\end{array}$ & $\begin{array}{c}\text { Annual } \\
\text { rainfall } \\
(\mathrm{mm})\end{array}$ & $\begin{array}{c}\text { Mean annual } \\
\text { temperature } \\
{ }^{\circ} \mathrm{C}\end{array}$ \\
\hline 1 & $\mathrm{CF}$ & 315 & $\mathrm{~N}$ & 6445 & 440 & 650 & 7.90 \\
2 & $\mathrm{CF}$ & 68 & $\mathrm{~N}$ & 6735 & 360 & 700 & 7.00 \\
7 & $\mathrm{CF}$ & 73 & $\mathrm{G}$ & 4526 & 550 & 900 & 4.50 \\
8 & $\mathrm{CF}$ & 75 & $\mathrm{G}$ & 3836 & 680 & 1140 & 7.40 \\
& $\mathrm{X}$ & 132.8 & & 5385.5 & 507.5 & 847.5 & 6.7 \\
& $\mathrm{Sd}$ & 121.5 & & 1424.0 & 138.9 & 222.9 & 1.52 \\
3 & $\mathrm{H}$ & 125 & $\mathrm{G}$ & 6790 & 250 & 700 & 7.80 \\
4 & $\mathrm{H}$ & 66 & $\mathrm{G}$ & 5638 & 520 & 720 & 4.80 \\
5 & $\mathrm{H}$ & 439 & $\mathrm{~N}$ & 7511 & 390 & 650 & 5.50 \\
6 & $\mathrm{H}$ & 318 & $\mathrm{~N}$ & 8124 & 286 & 670 & 9.60 \\
& $\mathrm{X}$ & 237 & & 7015.8 & 361.5 & 685.0 & 6.9 \\
& $\mathrm{Sd}$ & 172.4 & & 1068.1 & 121.2 & 31.1 & 2.20 \\
& $\mathrm{X}$ & 184.9 & & 6200.6 & 434.5 & 766.3 & 6.8 \\
\hline
\end{tabular}

${ }^{\mathrm{l}} \mathrm{n}$ - number of cows per herd; CF - Czech Fleckvieh; H - Holstein; G - grazing herds, N - non-grazing herds; $\mathrm{x}$ - mean; sd - standard deviation.

All BMS were transported to the accredited National Reference Laboratory for raw milk analysis (according to ČSN EN ISO/IEC 17025) in the Research Institute for Cattle Breeding, Ltd. in Rapotin (Czech Republic). Data concerning daily milk performance were obtained from animal records kept by the Czech Moravia Breeders Corporation.

\section{Analyses and abbreviations of determined milk indicators}

The analytical procedures were described in the previous studies of Hanuš et al. (2007, 2010 a, b, 2011). Briefly, composition and physicochemical and technological properties of milk were determined according to the following methods:

- the fat, lactose and solids-not-fat (SNF) were measured using MilkoScan 133B (Foss Electric, Denmark);

- the crude and true protein and casein were determined by reference Kjeldahl's method using the instrument line Tecator with Kjeltec Auto Distillation unit 2200 (Foss-Tecator AB, Sweden) according to ČSN 57 0530;

- the somatic cell count (SCC) was determined using Fossomatic 90 instrument (Foss Electric, Denmark) according to ČSN EN ISO 13366-3; 
- the urea and the acetone (Ac) were determined by spectrophotometry at $420 \mathrm{~nm}$ and $485 \mathrm{~nm}$ wavelength, respectively using Spekol 11 instrument (Carl Zeiss Jena, Germany);

- the milk freezing point depression (MFP) values were analysed using a top cryoscope Cryo-Star automatic Funke-Gerber (Germany);

- the electric conductivity (EC) was measured using OK 102/1 (Radelkis, Hungary) conductometer at $20^{\circ} \mathrm{C}$ (in $\left.\mathrm{mS} / \mathrm{cm}\right)$;

- the active acidity $(\mathrm{pH})$ was measured using the $\mathrm{pH}-$ meter CyberScan $510(\mathrm{Eu}-$ tech Instruments) at $20^{\circ} \mathrm{C}$;

- the titration acidity (TA) was measured according to the standard ČSN 57 0530 ;

- the milk alcohol stability (AS) was determined with the help of the milk titration $(5 \mathrm{ml})$ by $96 \%$ ethanol to the creation of the first visible milk protein precipitated flakes;

- the fermentation ability (FAM-CL, FAM-CS and FAM-TCM; carried out according to standard ON 570534 by slightly modified procedure with thermophilic yoghurt culture YC-180-40-FLEX = Streptococcus thermophilus, Lactobacillus delbrueckii subsp. lactis and L. d. subsp. bulgaricus) was investigated by calculating the number of the colony forming units (CFU) using the classical plate cultivation method (at $30^{\circ} \mathrm{C}$ for 72 hours) with GTK M (Milcom Tabor) agar with the glucose monohydrate, triptone-peptone, dehydrated yeast extract and skim milk powder, according to standard ČSN ISO 6610;

- the fermentation ability of milk - titration acidity (FAM-T) and active acidity (FAM-pH) - was measured as mentioned above for TA or $\mathrm{pH}$, respectively;

- the rennet coagulation time ( $\mathrm{RCT})$ - time from the addition of rennet to milk to the beginning of coagulation (s);

- the curds quality (CQ) - subjective estimation of curds cake quality determined by the aspection and touch from 1 st (excellent) to 4 th (poor) class;

- the cheese curds firmness (CF) - depth of penetration of the corpuscle falling into curd cake in a standard way $(\mathrm{mm})$;

- the whey volume (WV) - obtained during the process of enzymatic cheesemaking from curds cake for $60 \mathrm{~min}(\mathrm{ml})$;

- the specific weight (SW) - was determined using Mohr's hydrostatic scale on the basis of Archimedes' law.

The following milk indicators were calculated - solids, whey protein, non-protein nitrogen (NPN), fat to crude protein ratio (F/CP), urea nitrogen in NPN ratio (UNR), casein number on crude protein basis (Cas-CP), casein number on true protein basis (Cas-TP), yoghurt Streptococci/Lactobacilli (FAM-RSL).

\section{Statistical analysis}

The GLM procedure of the SAS v. 9 program package was used for the calculation. Multi-factor analysis of variance with fixed effects as breed, season and feeding system was used for statistical evaluation of data set, according to the following model: 


$$
y_{i j k}=\mu+b_{i}+s_{j}+f_{k}+e_{i j k}
$$

where:

$y_{i j k}=$ independent variable (investigated milk indicator);

$\mu=$ general mean;

$b_{i}=$ effect of breed $(\mathrm{i}=2)$,

$s_{j}=$ effect of season $(\mathrm{j}=2)$,

$f_{k}=$ effect of feeding $(\mathrm{k}=2)$,

$e_{i j k}=$ random effect.

Some values (AC, SCC, FAM-CL, FAM-CS, FAM-TCM) were log transformed (Meloun and Militký, 1994; Hanuš et al., 2007) as the data were not normally distributed. These data are not presented in the Tables.

\section{Results}

\section{Effect of breed}

The effect of $\mathrm{H}$ and $\mathrm{CF}$ breeds that are predominating in the Czech Republic environment on the composition and physical and technological characteristics of bulk milk is given in Table 2. Milk yield in $\mathrm{CF}$ was lower $(\mathrm{P}<0.05)$ than in $\mathrm{H}$. Concentrations of milk fat, crude protein, casein, true protein and NPN in CF breed were higher $(\mathrm{P}<0.05)$ than in $\mathrm{H}$ while concentrations of lactose, urea and whey protein did not differ significantly $(\mathrm{P}>0.05)$ between breeds. Content of DM and SNF was higher $(\mathrm{P}<0.05)$ in $\mathrm{CF}$ than in $\mathrm{H}$, reflecting changes mainly in protein fractions. Although SCC was not different $(\mathrm{P}<0.05)$ between breeds, CF had numerically lower SCC (244 ths $/ \mathrm{ml})$ than $\mathrm{H}(282.56 \mathrm{ths} / \mathrm{ml})$ and $\operatorname{logSCC}$ tended to be lower in CF than in $\mathrm{H}(\mathrm{P}=0.0567$, data not given). Physical indicators of milk ( $\mathrm{pH}$ and MFP) were not affected by the breed except for EC that was lower $(\mathrm{P}<0.05)$ in $\mathrm{CF}$ compared to $\mathrm{H}$. The remaining milk indicators (RCT, CQ, CF, WV, SW, AS, TA, CAS-CP, CAS-TP, FAM-T, FAM-pH, FAM-CL, FAM-CS, FAM-TCM, and FAM-RSL) were not affected $(\mathrm{P}>0.05)$ by the cattle breed.

Table 2. Effect of the cattle breed ${ }^{1}$ on chemical, physical and technological properties ${ }^{2}$ of raw milk

\begin{tabular}{l|r|r|r|c}
\hline \multicolumn{1}{c|}{ Item } & CF & H & SEM & P \\
\hline \multicolumn{1}{c}{1} & \multicolumn{1}{c}{2} & \multicolumn{1}{c}{3} & 4 & \multicolumn{1}{c}{5} \\
\hline Milk yield $(\mathrm{kg})$ & 5386 & 7016 & 77.89 & $<0.001$ \\
Solids $(\mathrm{g} / 100 \mathrm{~g})$ & 12.86 & 12.45 & 0.05 & $<0.001$ \\
Solids-non-fat (g/100 g) & 8.86 & 8.73 & 0.02 & $<0.001$ \\
Fat (g/100 g) & 3.90 & 3.72 & 0.06 & 0.022 \\
Lactose (g/100 g) & 4.91 & 4.90 & 0.02 & 0.744 \\
Urea (mg/dl) & 29.05 & 29.03 & 1.40 & 0.992 \\
Acetone (mg/l) & 4.29 & 4.66 & 0.46 & 0.577 \\
\hline
\end{tabular}


Table 2 contd.

\begin{tabular}{|c|c|c|c|c|}
\hline 1 & 2 & 3 & 4 & 5 \\
\hline Somatic cell count (thous/ml) & 244 & 283 & 18.73 & 0.151 \\
\hline Alcohol stability (ml) & 0.464 & 0.441 & 0.03 & 0.603 \\
\hline Titration acidity $\left({ }^{\circ} \mathrm{SH}\right)$ & 7.78 & 7.82 & 0.12 & 0.834 \\
\hline Electric conductivity $(\mathrm{mS} / \mathrm{cm})$ & 3.93 & 4.08 & 0.04 & 0.015 \\
\hline $\mathrm{pH}$ & 6.68 & 6.66 & 0.02 & 0.294 \\
\hline Milk freezing point depression $\left({ }^{\circ} \mathrm{C}\right)$ & -0.526 & -0.526 & 0.01 & 0.938 \\
\hline Rennet coagulation time (sec) & 121 & 115 & 3.83 & 0.289 \\
\hline Curd quality (class) & 2.53 & 2.56 & 0.11 & 0.834 \\
\hline Cheese curd firmness $(\mathrm{cm})$ & 1.81 & 1.83 & 0.01 & 0.166 \\
\hline Whey volume (ml) & 34.16 & 34.53 & 0.23 & 0.252 \\
\hline Specific weight $\left(\mathrm{g} / \mathrm{cm}^{3}\right)$ & 1.03 & 1.03 & 0.01 & 0.281 \\
\hline Crude protein $(\mathrm{CP})(\mathrm{g} / 100 \mathrm{~g})$ & 3.37 & 3.25 & 0.02 & $<0.001$ \\
\hline Casein $(\mathrm{g} / 100 \mathrm{~g})$ & 2.66 & 2.58 & 0.02 & 0.001 \\
\hline True protein $(\mathrm{TP})(\mathrm{g} / 100 \mathrm{~g})$ & 3.16 & 3.07 & 0.01 & $<0.001$ \\
\hline Whey protein $(\mathrm{g} / 100 \mathrm{~g})$ & 0.50 & 0.49 & 0.01 & 0.565 \\
\hline Non-protein nitrogen (NPN) (g/100 g) & 0.21 & 0.18 & 0.01 & 0.033 \\
\hline Urea $\mathrm{N}$ in NPN $(\%)$ & 43.83 & 48.50 & 2.64 & 0.171 \\
\hline Fat/crude protein & 1.16 & 1.15 & 0.02 & 0.482 \\
\hline Casein number on $\mathrm{CP}$ basis (\%) & 79.14 & 79.58 & 0.42 & 0.467 \\
\hline Casein number on TP basis (\%) & 84.26 & 84.11 & 0.35 & 0.763 \\
\hline S. aureus $(\mathrm{CFU} / \mathrm{ml})$ & 13.75 & 60.62 & 26.47 & 0.215 \\
\hline Str. agal. $(\mathrm{CFU} / \mathrm{ml})$ & 35.94 & 35.00 & 26.61 & 0.980 \\
\hline FAM-T ( $\left.{ }^{\circ} \mathrm{SH}\right)$ & 23.20 & 22.17 & 1.26 & 0.567 \\
\hline FAM-pH & 4.82 & 4.80 & 0.02 & 0.466 \\
\hline FAM-CL (CFU/ml) & $3.2 * 10^{7}$ & $3.0^{*} 10^{7}$ & $3.2 * 10^{6}$ & 0.602 \\
\hline FAM-CS (CFU/ml) & $1.5 * 10^{9}$ & $7.8^{*} 10^{8}$ & $3.4 * 10^{8}$ & 0.146 \\
\hline FAM-TCM (CFU/ml) & $1.5 * 10^{9}$ & $8.1 * 10^{8}$ & $3.5 * 10^{8}$ & 0.147 \\
\hline FAM-RSL & 41.61 & 33.01 & 5.24 & 0.251 \\
\hline
\end{tabular}

${ }^{\mathrm{I}} \mathrm{CF}-$ Czech Fleckvieh, $\mathrm{H}-$ Holstein.

${ }^{2}$ Milk indicators: FAM-T - fermentation ability of milk by titration acidity, FAM-pH - fermentation ability of milk by active acidity, FAM-CL, FAM-CS and FAM-TCM - fermentation ability - count of lactobacilli, streptococci and total count of microorganisms, respectively, FAM-RSL - fermentation ability - yoghurt Streptococci/ Lactobacilli ratio.

\section{Effect of season}

In the current study, the concentration of $\mathrm{DM}, \mathrm{SNF}$ and fat was lower $(\mathrm{P}=0.0001$; $\mathrm{P}<0.001$ and $\mathrm{P}<0.05$, respectively) during summer season ( $\mathrm{S}$ ) than in winter season (W, see Table 3). Similarly, content of crude protein, casein, true protein and whey protein were lower $(\mathrm{P}<0.05)$ in $\mathrm{S}$ than in $\mathrm{W}$ while content of NPN showed an oppo- 
site trend $(\mathrm{P}<0.05)$. Content of lactose and urea was not affected $(\mathrm{P}>0.05)$ by the season. The values of milk AC were in the physiological range and tended to be higher in $\mathrm{S}$ than in $\mathrm{W}(\mathrm{P}=0.0834)$, the $\log \mathrm{AC}$ values then differed significantly $(\mathrm{P}<0.05)$ in dependence on season (data not given). Although the season is one of the factors that can influence bulk milk SCC in the herd, no effect of season on SCC (P>0.05) was observed in our study. Summer milk $(\mathrm{S})$ had higher $(\mathrm{P}<0.05) \mathrm{EC}(4.10 \mathrm{mS} / \mathrm{cm})$ and $\mathrm{pH}(6.70)$ in comparison to winter milk (W) being $3.91 \mathrm{mS} / \mathrm{cm}$ and 6.63 , respectively. In view of the technological and coagulation properties of milk, the effect of season was not significant $(\mathrm{P}>0.05)$ for most of indicators such us RCT, CF, WV, SW, AS, TA, CAS-CP, CAS-TP, FAM-T, FAM-CL, FAM-CS, FAM-TCM and FAMRSL. On the other hand CQ was higher $(\mathrm{P}<0.05)$ in $\mathrm{W}$ than in $\mathrm{S}$ while FAM-pH was higher $(\mathrm{P}<0.05)$ in $\mathrm{S}$ in comparison to $\mathrm{W}$.

Table 3. Effect of the season ${ }^{1}$ on chemical, physical and technological properties ${ }^{2}$ of raw milk

\begin{tabular}{|c|c|c|c|c|}
\hline Item & S & W & SEM & $\mathrm{P}$ \\
\hline 1 & 2 & 3 & 4 & 5 \\
\hline Milk yield (kg) & 6201 & 6201 & 77.89 & 1.000 \\
\hline Solids (g/100 g) & 12.45 & 12.76 & 0.05 & 0.001 \\
\hline Solids-non-fat (g/100 g) & 8.74 & 8.85 & 0.02 & 0.001 \\
\hline Fat $(g / 100 g)$ & 3.71 & 3.91 & 0.06 & 0.015 \\
\hline Lactose $(\mathrm{g} / 100 \mathrm{~g})$ & 4.89 & 4.92 & 0.02 & 0.206 \\
\hline Urea $(\mathrm{mg} / \mathrm{dl})$ & 30.21 & 27.87 & 1.40 & 0.242 \\
\hline Acetone (mg/l) & 5.05 & 3.90 & 0.46 & 0.083 \\
\hline Somatic cell count (thous $/ \mathrm{ml}$ ) & 274 & 252 & 18.73 & 0.405 \\
\hline Alcohol stability (ml) & 0.489 & 0.416 & 0.03 & 0.107 \\
\hline Titration acidity $\left({ }^{\circ} \mathrm{SH}\right)$ & 7.68 & 7.92 & 0.12 & 0.161 \\
\hline Electric conductivity $(\mathrm{mS} / \mathrm{cm})$ & 4.10 & 3.91 & 0.04 & 0.002 \\
\hline $\mathrm{pH}$ & 6.70 & 6.63 & 0.02 & 0.003 \\
\hline Milk freezing point depression $\left({ }^{\circ} \mathrm{C}\right)$ & -0.526 & -0.525 & 0.01 & 0.214 \\
\hline Rennet coagulation time (sec) & 117 & 118 & 3.83 & 0.831 \\
\hline Curd quality (class) & 2.28 & 2.81 & 0.11 & 0.001 \\
\hline Cheese curd firmness $(\mathrm{cm})$ & 1.81 & 1.83 & 0.01 & 0.166 \\
\hline Whey volume (ml) & 34.37 & 34.31 & 0.23 & 0.848 \\
\hline Specific weight $\left(\mathrm{g} / \mathrm{cm}^{3}\right)$ & 1.03 & 1.03 & 0.01 & 0.950 \\
\hline Crude protein $(\mathrm{CP})(\mathrm{g} / 100 \mathrm{~g})$ & 3.27 & 3.34 & 0.02 & 0.003 \\
\hline Casein $(\mathrm{g} / 100 \mathrm{~g})$ & 2.59 & 2.66 & 0.02 & 0.002 \\
\hline True protein $(\mathrm{TP})(\mathrm{g} / 100 \mathrm{~g})$ & 3.06 & 3.17 & 0.01 & $<0.001$ \\
\hline Whey protein $(\mathrm{g} / 100 \mathrm{~g})$ & 0.48 & 0.51 & 0.01 & 0.039 \\
\hline Non-protein nitrogen (NPN) (g/100 g) & 0.20 & 0.18 & 0.01 & 0.037 \\
\hline Urea $\mathrm{N}$ in NPN $(\%)$ & 46.17 & 46.65 & 2.64 & 0.898 \\
\hline Fat/crude protein & 1.14 & 1.17 & 0.02 & 0.183 \\
\hline
\end{tabular}


Table 3 - contd.

\begin{tabular}{lccccc}
\hline \multicolumn{1}{c|}{1} & 2 & 3 & 4 & 5 \\
\hline Casein number on CP basis (\%) & 79.19 & 79.54 & 0.42 & 0.556 \\
Casein number on TP basis (\%) & 84.43 & 83.94 & 0.35 & 0.327 \\
S. aureus $(\mathrm{CFU} / \mathrm{ml})$ & 17.81 & 56.56 & 26.47 & 0.305 \\
Str. agal. $(\mathrm{CFU} / \mathrm{ml})$ & 37.19 & 33.75 & 26.61 & 0.928 \\
FAM-T $\left({ }^{\circ} \mathrm{SH}\right)$ & 21.83 & 23.54 & 1.26 & 0.343 \\
FAM-pH & 4.86 & 4.76 & 0.02 & 0.006 \\
FAM-CL $(\mathrm{CFU} / \mathrm{ml})$ & $3.0^{*} 10^{7}$ & $3.2^{*} 10^{7}$ & $3.2^{*} 10^{6}$ & 0.573 \\
FAM-CS $(\mathrm{CFU} / \mathrm{ml})$ & $1.5^{*} 10^{9}$ & $7.6^{*} 10^{8}$ & $3.4^{*} 10^{8}$ & 0.132 \\
FAM-TCM $(\mathrm{CFU} / \mathrm{ml})$ & $1.5^{*} 10^{9}$ & $7.9^{*} 10^{8}$ & $3.5^{*} 10^{8}$ & 0.135 \\
FAM-RSL & 41.27 & 33.34 & 5.24 & 0.289 \\
\hline
\end{tabular}

${ }^{1} \mathrm{~S}$ - summer season (samples collected in June and August), W - winter season (samples collected in December and February).

${ }^{2}$ Milk indicators: FAM-T - fermentation ability of milk by titration acidity, FAM-pH - fermentation ability of milk by active acidity, FAM-CL, FAM-CS and FAM-TCM - fermentation ability - count of lactobacilli, streptococci and total count of microorganisms, respectively, FAM-RSL - fermentation ability - yoghurt Streptococci/ Lactobacilli ratio.

\section{Effect of the type of feeding}

The effect of the type of feeding on milk composition and its physical and technological properties is shown in Table 4. Milk yield in grazing herds $(\mathrm{G})$ was lower $(\mathrm{P}<0.05)$ than in non-grazing herds $(\mathrm{N})$. Content of DM was not affected by the type of feeding while content of fat was higher $(\mathrm{P}<0.05)$ in $\mathrm{G}$ than in $\mathrm{N}$. Concentration of lactose and all studied protein fractions were lower $(\mathrm{P}<0.05)$ in $\mathrm{G}$ than in $\mathrm{N}$. Content of SNF was lower $(\mathrm{P}<0.05)$ in $\mathrm{G}$ than in $\mathrm{N}$ reflecting changes in protein fractions and lactose. SCC tended to be higher in grazing cows $(\mathrm{G})$ in comparison to non-grazing $(\mathrm{N}, \mathrm{P}=0.0995)$ while log SCC differed significantly $(\mathrm{P}<0.05$, data not given). From physical indicators of milk only $\mathrm{pH}$ was not affected by the type of feeding. MFP was lower $(\mathrm{P}<0.05)$ in $\mathrm{G}$ compared to $\mathrm{N}$. Value of $\mathrm{EC}$ in $\mathrm{G}$ tended to be higher than in $\mathrm{N}(\mathrm{P}=0.0578)$. In view of the technological and coagulation properties of milk, the effect of the type of feeding was not significant for most of indicators such us RCT, WV, SW, AS, TA, CAS-CP, CAS-TP, FAM-T, FAM-pH, FAM-CL, FAM-CS, FAMTCM and FAM-RSL $(\mathrm{P}>0.05)$. On the other hand CQ and CF were higher $(\mathrm{P}<0.05)$ in $\mathrm{G}$ than in $\mathrm{N}$.

Table 4. Effect of the type of feeding ${ }^{1}$ on chemical, physical and technological properties ${ }^{2}$ of raw milk

\begin{tabular}{l|r|r|r|c}
\hline \multicolumn{1}{c|}{ Item } & $\mathrm{G}$ & $\mathrm{N}$ & $\mathrm{SEM}$ & $\mathrm{P}$ \\
\hline \multicolumn{1}{c}{1} & 2 & 3 & 4 & 5 \\
\hline Milk yield $(\mathrm{kg})$ & 5198 & 7204 & 77.89 & $<0.001$ \\
Solids $(\mathrm{g} / 100 \mathrm{~g})$ & 12.60 & 12.61 & 0.05 & 0.868 \\
Solids-non-fat $(\mathrm{g} / 100 \mathrm{~g})$ & 8.71 & 8.89 & 0.02 & $<0.001$ \\
Fat $(\mathrm{g} / 100 \mathrm{~g})$ & 3.89 & 3.73 & 0.06 & 0.035 \\
\hline
\end{tabular}


Table 4 - contd.

\begin{tabular}{|c|c|c|c|c|}
\hline 1 & 2 & 3 & 4 & 5 \\
\hline Lactose $(\mathrm{g} / 100 \mathrm{~g})$ & 4.86 & 4.94 & 0.02 & 0.005 \\
\hline Urea $(\mathrm{mg} / \mathrm{dl})$ & 23.49 & 34.59 & 1.40 & $<0.001$ \\
\hline Acetone (mg/l) & 4.27 & 4.67 & 0.46 & 0.542 \\
\hline Somatic cell count (thous/ml) & 285 & 241 & 18.73 & 0.099 \\
\hline Alcohol stability (ml) & 0.43 & 0.47 & 0.03 & 0.330 \\
\hline Titration acidity $\left({ }^{\circ} \mathrm{SH}\right)$ & 7.72 & 7.88 & 0.12 & 0.337 \\
\hline Electric conductivity $(\mathrm{mS} / \mathrm{cm})$ & 4.06 & 3.95 & 0.04 & 0.058 \\
\hline $\mathrm{pH}$ & 6.66 & 6.67 & 0.02 & 0.679 \\
\hline Milk freezing point depression $\left({ }^{\circ} \mathrm{C}\right)$ & -0.525 & -0.527 & 0.01 & 0.024 \\
\hline Rennet coagulation time (sec) & 118 & 118 & 3.82 & 0.986 \\
\hline Curd quality (class) & 2.91 & 2.19 & 0.11 & $<0.001$ \\
\hline Cheese curd firmness $(\mathrm{cm})$ & 1.84 & 1.80 & 0.01 & 0.004 \\
\hline Whey volume (ml) & 34.12 & 34.56 & 0.23 & 0.183 \\
\hline Specific weight $\left(\mathrm{g} / \mathrm{cm}^{3}\right)$ & 1.03 & 1.03 & 0.01 & $<0.001$ \\
\hline Crude protein $(\mathrm{CP})(\mathrm{g} / 100 \mathrm{~g})$ & 3.22 & 3.39 & 0.02 & $<0.001$ \\
\hline Casein $(\mathrm{g} / 100 \mathrm{~g})$ & 2.56 & 2.68 & 0.02 & $<0.001$ \\
\hline True protein $(\mathrm{TP})(\mathrm{g} / 100 \mathrm{~g})$ & 3.04 & 3.19 & 0.01 & $<0.001$ \\
\hline Whey protein $(\mathrm{g} / 100 \mathrm{~g})$ & 0.47 & 0.51 & 0.01 & 0.024 \\
\hline Non-protein nitrogen (NPN) (g/100 g) & 0.18 & 0.20 & 0.01 & 0.285 \\
\hline Urea $\mathrm{N}$ in NPN $(\%)$ & 39.04 & 53.78 & 2.64 & $<0.001$ \\
\hline Fat/crude protein & 1.21 & 1.10 & 0.02 & $<0.001$ \\
\hline Casein number on $\mathrm{CP}$ basis (\%) & 79.61 & 79.11 & 0.42 & 0.406 \\
\hline Casein number on TP basis (\%) & 84.37 & 84.00 & 0.35 & 0.459 \\
\hline S. aureus $(\mathrm{CFU} / \mathrm{ml})$ & 59.06 & 15.31 & 26.47 & 0.247 \\
\hline Str. agal. (CFU/ml) & 64.37 & 6.56 & 26.61 & 0.130 \\
\hline FAM-T $\left({ }^{\circ} \mathrm{SH}\right)$ & 22.20 & 23.17 & 1.26 & 0.588 \\
\hline FAM-pH & 4.81 & 4.81 & 0.02 & 0.855 \\
\hline FAM-CL (CFU/ml) & $3.0^{*} 10^{7}$ & $3.1 * 10^{7}$ & $3.1 * 10^{6}$ & 0.774 \\
\hline FAM-CS (CFU/ml) & $7.9 * 10^{8}$ & $1.5^{*} 10^{9}$ & $3.4 * 10^{8}$ & 0.159 \\
\hline FAM-TCM (CFU/ml) & $8.2 * 10^{8}$ & $1.5^{*} 10^{8}$ & $3.5^{*} 10^{8}$ & 0.160 \\
\hline FAM-RSL & 32.07 & 42.55 & 5.24 & 0.163 \\
\hline
\end{tabular}

${ }^{\mathrm{I}} \mathrm{G}$ - grazing herds, $\mathrm{N}$ - non-grazing herds.

${ }^{2}$ Milk indicators: FAM-T - fermentation ability of milk by titration acidity, FAM-pH - fermentation ability of milk by active acidity, FAM-CL, FAM-CS and FAM-TCM - fermentation ability - count of lactobacilli, streptococci and total count of microorganisms, respectively, FAM-RSL - fermentation ability - yoghurt Streptococci/Lactobacilli ratio. 


\section{Discussion}

\section{Effect of breed}

Breed is the main genetic aspect affecting milk quality characteristics and, consequently, cheese-making technology and quality of products. Differences among dairy cattle breeds in level of production and chemical and technological properties of milk have been widely demonstrated in many studies and differences between some breeds, mainly Holstein and Jersey that are considered predominant in global milk production, are well known (Auldist et al., 2002; De Marchi et al., 2007). However, breed and farming systems of dairy cows differ significantly between countries and this results in differences in the composition of bovine milk (Schönfeldt et al., 2012). Differences in milk yield between $\mathrm{CF}$ and $\mathrm{H}$ found in our study are in agreement with findings of Wolfová et al. (2007) and Hanuš et al. (2010 a) characterising ordinary population of $\mathrm{CF}$ and $\mathrm{H}$ cows bred in the Czech Republic environment. On the other hand, in the studies of Hanuš et al. (2007) and Janů et al. (2007 a) performed on high and average yielding $\mathrm{CF}$ and $\mathrm{H}$ herds, reported milk yield in both average breeds was higher than in our study.

In the current study, milk fat content from CF cows was $3.9 \mathrm{~g} / 100 \mathrm{~g}$ and it was higher $(\mathrm{P}<0.05)$ than milk fat content of $\mathrm{H}$ breed $(3.72 \mathrm{~g} / 100 \mathrm{~g})$. Similar values were also documented in other studies with the same breeds in the Czech Republic (Hanuš et al., 2007, 2010 b; Janů et al., 2007 a; Wolfová et al., 2007) confirming variations in milk fat content among dairy breeds documented also in other literature works (Auldist et al., 2002; De Marchi et al., 2007). Content of lactose was similar ( $\mathrm{P}>0.05$ ) in both breeds being 4.91 and $4.90 \mathrm{~g} / 100 \mathrm{~g}$ for $\mathrm{CF}$ and $\mathrm{H}$, respectively and it corresponds to common physiological ranges described in the literature (Hanuš et al., 2007; Janů et al., 2007 a).

In the present study, concentrations of crude protein, casein, true protein and NPN in CF breed were higher $(\mathrm{P}<0.05)$ than in $\mathrm{H}$ while concentrations of whey protein did not differ significantly $(\mathrm{P}>0.05)$ between breeds. Similar findings were reported by Wolfová et al. (2007) and Hanuš et al. (2010 a). Values determined in our study for individual protein and nitrogen fractions in individual breeds are similar to those reported for CF breed by Wolfová et al. (2007) or Hanuš et al. (2007, 2010 a) and for Czech population of $\mathrm{H}$ breed by Janů et al. (2007 a) and Hanuš et al. (2010 a).

SCC as an indicator of mammary gland health is evaluated routinely in terms of mastitis resistance determination in dairy cattle (Hanuš et al., 2011). Differences in SCC between breeds are documented in the literature (Berry et al., 2007). Although SCC was not different $(\mathrm{P}>0.05)$ between breeds, CF had numerically lower SCC (244 ths $/ \mathrm{ml})$ than $\mathrm{H}(282.56 \mathrm{ths} / \mathrm{ml})$ and $\operatorname{logSCC}$ tended to be lower in CF than in $\mathrm{H}(\mathrm{P}=0.0567)$. Our findings, although non-significant, are in agreement with $\mathrm{Za}-$ vadilová et al. (2011) who determined genetic parameters for somatic cell score (=log SCC) in the first three lactations of Czech H and CF. They found substantial differences between those two breeds with stronger genetic influences on SCC in $\mathrm{H}$ than in CF. Similarly, Frelich and Šlachta (2009) found higher SCC in H than in $\mathrm{CF}$. 
Significantly lower value of milk EC in CF as compared to H (Table 2) could be logically expected because of its lower SCC (in accordance with Hanuš et al., 2007 and Janů et al., 2007 a). Similarly the significantly higher values of DM and SNF in $\mathrm{CF}$ as compared to $\mathrm{H}$ could be logically caused by its lower milk yield. There could be also similar reasons for significantly higher values $(\mathrm{CF})$ of fat, crude protein and casein percentage.

Besides milk quality, breed of cow and herd are important sources of variation for coagulation properties of milk (De Marchi et al., 2007). In the present study, none of these milk indicators (shown in Table 2) were affected by the cattle breed $(\mathrm{P}>0.05)$. This is in disagreement with Ikonen et al. (2004), Malacarne et al. (2006) or De Marchi et al. (2007) who found a wide variation in milk coagulation properties among different breeds. The indicators of cheese making, such as RTC, CQ, CF and WV, were also different between $\mathrm{CF}$ and $\mathrm{H}$ as documented by Hanuš et al. (2007) and Janů et al. (2007 a). This discrepancy was probably caused by differences in factors that are involved in the cheese-making ability of milk such as titratable acidity (Formaggioni et al., 2001), somatic cell count (Politis and Ng-Kwai-Hang, 1988), protein and casein contents and calcium and phosphorus concentrations (Summer et al., 2002).

\section{Effect of season}

Season is considered as a substantial source of variation in composition and renneting properties of milk (Heck et al., 2009; Chládek et al., 2011; Litwinczuk et al., 2011; Kriščiunaite et al., 2012). In the current study, the concentrations of DM, SNF and fat were lower $(\mathrm{P}<0.05)$ during summer season $(\mathrm{S})$ than in winter season $(\mathrm{W})$. Lower fat content in summer milk was caused by decreased fat concentration in both grazing $(3.87 \mathrm{~g} / 100 \mathrm{~g})$ and non-grazing herds (3.56 g/100 g, data not presented). Similar findings were reported by Heck et al. (2009), Larsen et al. (2010), Chládek et al. (2011) and Kriščiunaite et al. (2012), confirming suggestions that these differences are most likely feed-related and recognised as normal in many countries (Lindmark-Månsson et al., 2003; Heck et al., 2009; Larsen et al., 2010; Chládek et al., 2011). However, as mentioned by Larsen et al. (2010) other conditions may also affect milk composition, such as heat stress during summer (Chládek et al., 2011). Similarly to our results, Heck et al. (2009) and Chládek et al. (2011) did not find significant differences in lactose content between summer and winter season, however they determined the lowest lactose level in autumn milk that differed significantly from values measured in spring or summer.

Content of crude protein, casein, true protein and whey protein was lower $(\mathrm{P}<0.05)$ in $\mathrm{S}$ than in $\mathrm{W}$ while content of NPN showed an opposite trend $(\mathrm{P}<0.05)$. Lower protein values and higher NPN values were observed when comparing data from grazing and non-grazing herds between seasons (data not presented) suggesting, in agreement with Frelich et al. (2011), that the feeding system was not a major factor determining these seasonal changes. Similar findings were also reported in the literature (Lindmark-Månsson et al., 2003; Heck et al., 2009; Litwinczuk et al., 2011; Kriščiunaite et al., 2012). In this study, milk urea did not differ significantly $(\mathrm{P}>0.05)$ between summer and winter seasons. This is in agreement with Lindmark-Månsson 
et al. (2003). On the other hand, Heck et al. (2009) in their survey found $(\mathrm{P}<0.001)$ minimum urea values in December and maximum in August. According to Roy et al. (2011) seasonal differences in milk urea are likely influenced by feeding changes associated with season so the discrepancy between findings concerning milk urea can be at least partly explained by differences in feeding management. Indeed, within summer season, concentration of milk urea in grazing herds was $26.6 \mathrm{mg} / \mathrm{dl}$ while in non-grazing herds $33.8 \mathrm{mg} / \mathrm{dl}$ (data not presented).

Although the season is one of the factors that can influence bulk milk SCC in the herd, no effect of season on SCC $(\mathrm{P}>0.05)$ was observed in our study; although S samples had numerically higher SCC that originated from grazing herds with SCC of $303 \mathrm{ths} / \mathrm{ml}$ in comparison to non-grazing herds (246 ths $/ \mathrm{ml}$, data not presented). However, Kriščiunaite et al. (2012) reported that the highest milk SCC in Estonian herds was observed in summer compared to other seasons. Also, Heck et al. (2009) found $(\mathrm{P}<0.001)$ maximum SCC in August milk and minimum value in November milk. On the other hand, Frelich et al. (2011) found higher milk SCC in the winter than in the summer season in both feeding systems.

Summer milk (S) had higher $(\mathrm{P}<0.05) \mathrm{EC}(4.10 \mathrm{mS} / \mathrm{cm})$ and $\mathrm{pH}(6.70)$ in comparison to winter milk (W) being $3.91 \mathrm{mS} / \mathrm{cm}$ and 6.63 , respectively. The $\mathrm{pH}$ values are in contrast to Chládek et al. (2011) who found higher values in winter and spring in comparison to summer and autumn.

Studies on the effect of season on milk coagulation properties are inconsistent. In the present study, the effect of season was not significant for most of indicators (see Table 3) except for CQ that was higher $(\mathrm{P}<0.05)$ in $\mathrm{W}$ and FAM-pH that was higher $(\mathrm{P}<0.05)$ in $\mathrm{S}$. According to De Marchi et al. (2007), RCT and curd firmness were on average slightly better in September and October and the worst values were obtained during summer. On the other hand, Chládek et al. (2011) found significantly lower RCT in summer than in other seasons. Similarly, Hanuš et al. (2010 a) and Kriščiunaite et al. (2012) reported the shortest RCT in summer season. These discrepancies could be probably explained by differences in climatic conditions in above mentioned studies as it was also confirmed in other studies (Summer et al., 1999) which suggested that the unfavourable climatic conditions (high temperature and humidity) are able to affect the metabolic and nutritional status of the cows, which is associated with total aptitude to the cheesemaking.

\section{Effect of the type of feeding}

The breeding of two most common dairy breeds, $\mathrm{H}$ and CF, in the Czech Republic relies on two feeding strategies, a pasture-based feeding system with a seasonal pasture from May to October followed by silage feeding indoors for the rest of the year, and a silage-based feeding system with the indoor silage feeding without any access to pasture throughout the year (Frelich and Šlachta, 2011). In the present study, milk yield in grazing herds $(\mathrm{G}, 5197.50 \mathrm{~kg})$ was lower $(\mathrm{P}<0.05)$ than in nongrazing herds (N, $7203.75 \mathrm{~kg}$ ). Our findings were confirmed in many studies comparing pasture-based feeding system with the conventional ones (Kolver and Muller, 1998; White et al., 2001). The differences in milk production between grazing and non-grazing herds are likely related to differences in energy requirements for main- 
tenance related to walking and grazing activity (Agnew and Yan, 2000) and to differences in energy intake that is a primary limiting nutrient for high-yielding dairy cows on pasture (Kolver and Muller, 1998; Bargo et al., 2002). Lower concentration of lactose $(\mathrm{P}<0.05)$ in $\mathrm{G}$ was obtained in our study and it is in agreement with previous studies of Hanuš et al. (2007) and Janů et al. (2007 a) who mentioned higher lactose levels in higher milk yield. Decreased content of all protein fractions, as crude protein, casein, true protein, whey protein in milk of grazing herds $(G, P<0.05)$ was also documented in a study of Bargo et al. (2002) and in the case of total casein and some casein fractions also in Jõudu et al. (2008). On the other hand, White et al. (2001) and Kriščiunaite et al. (2012) did not find differences in the protein percentage between pasture and confinement cows or between indoor and outdoor housing period, respectively. Jõudu et al. (2008) suggested that these discrepancies may be caused by differences in the experimental design.

The concentration of milk urea can be used as an indicator of the nutritional status of the dairy herd and it can be influenced by feeding changes associated with season (Arunvipas et al., 2004), mainly with changes in pasture protein and energy components (Roy et al., 2011). Furthermore, a positive non-linear association between milk urea and milk yield was observed in previous studies of Hanuš et al. (2007, 2011) and Janů et al. (2007 a). In our study, content of urea in grazing herds $(\mathrm{G}, 23.49 \mathrm{mg} / \mathrm{dl})$ was considerably lower $(\mathrm{P}<0.001)$ than in conventionally fed herds $(\mathrm{N}, 34.59 \mathrm{mg} / \mathrm{dl})$, confirming above mentioned findings.

In conclusion, results of our study provide insight into the main factors influencing milk composition and technological properties of bovine milk in the Czech Republic environment. The ratio between main milked breeds in dairy cattle population in the Czech Republic is balanced approximately $1: 1$. The Czech Fleckvieh breed had a lower milk yield but produced milk with higher concentration of the main milk components in comparison to the Czech population of Holstein breed. Physical and technological properties of milk were comparable between both breeds. Large seasonal variations were determined in concentrations of the main milk components with lower values in summer season compared to winter season. The most pronounced changes in milk composition were caused by the type of feeding with a clear decrease in milk yield and concentration of lactose and all studied protein fractions and higher content of fat in grazing herds compared to non-grazing herds. Because breed and farming systems of dairy cows differ significantly between countries and result in differences in the composition of bovine milk, the importance of country specific compositional values for bovine milk becomes apparent because it forms the basis of consumer education and various retail practices. Similar results could also contribute to reliable data about milk indicators for official milk recording for possible inclusion into breeding and dairy cattle improvement. Furthermore, results of similar studies can be also used to monitor changes in milk composition and renneting properties over the last decades, reflecting changes in breeding and feeding strategies in management of dairy herds and to identify possible future trends. Marked changes in the dairy management in the Czech Republic in the past decades resulted in a current relatively steady state concerning the ratio between the main two milked breeds that will probably be kept in the following decades. Concerning the 
feeding regimes, lower milk yield, protein and lactose content typical for the pasturebased feeding system are compensated with positive effects on udder health, somatic cell count, fatty acid profile and anti-oxidant substances as well documented in many studies done in the Czech Republic (Janů et al., 2007 b; Samková et al., 2009; Hanuš et al., 2010 a, b; Frelich et al., 2011, 2012). To sum up, some differences exist depending on breed, feeding system or season, mainly related to fat and protein content that may slightly affect cheese properties but without having considerable effect on quality of retail dairy products. In the light of increased demands of consumers for healthier dairy products and increased interest in welfare of animals, pasture-based feeding system will probably not be reduced at the expense of conventional one; however, greater regional differences between using these two systems can be expected within the country. Thus breeding goals for both breeds in the Czech Republic will be focused not only on milk production traits but it can be expected that other selection criteria will be included into breeding programmes such as robustness (in terms as defined by Veerkamp et al., 2013), somatic cell count, length of productive life or reproductive performance.

\section{References}

A g n ew R.E., Yan T. (2000). Impact of recent research on energy feeding systems for dairy cattle. Livest. Prod. Sci., 66: 197-215.

A runvipas P., Van L e e u w en J.A., D oh o o I.R., Ke e fe G.P. (2004). Bulk tank milk urea nitrogen: Seasonal patterns and relationship to individual cow milk urea nitrogen values. Can. J. Vet. Res., 68: 169-174.

Auldist M., Mullins C., O'Brien B., O ' Kennedy B.T., Guine e T. (2002). Effect of cow breed on milk coagulation properties. Milchwissenschaft, 5: 140-143.

B arg o F., Mulle r L.D., D e l a h o y J.E., C a s s idy T.W. (2002). Performance of high producing dairy cows with three different feeding systems combining pasture and total mixed rations. J. Dairy Sci., 85: 2948-2963.

B e rry D.P., L e e J.M., M a c d o nald K.A., S t a fford K., Mat thew s L., R o che J.R. (2007). Associations among body condition score, body weight, somatic cell count, and clinical mastitis in seasonally calving dairy cattle. J. Dairy Sci., 90: 637-648.

Chlád ek G., Č e j n a V., F a lt a D., Mách al L. (2011). Effect of season and herd on rennet coagulation time and other parameters of milk technological quality in Holstein dairy cows. Acta Univ. Agric. Silvic. Mendel. Brun., LIX, 5: 113-118.

De Marchi M., Dal Z otto R., Cass andro M., Bittante G. (2007). Milk coagulation ability of five dairy cattle breeds. J. Dairy Sci., 90: 3986-3992.

Formagg i oni R., Mal a c arne M., S ummer A., Foss a E., Mariani P. (2001). Milk with abnormal acidity. The role of phosphorus content and the rennet-coagulation properties of Italian Friesian herd milk. Ann. Fac. Med. Vet. Univ. Parma 21: 261-268.

Frelich J., Šlacht a M. (2011). Impact of seasonal grazing on udder health of cows. Acta Univ. Agric. Silvic. Mendel. Brun., LIX, 1: 53-58.

Freli ch J., Šl a ch ta M., H a nuš O., Š pičk a J., S a m ková E., W ęg lar z A., Z a ple ta 1 P. (2012). Seasonal variation in fatty acid composition of cow milk in relation to the feeding system. Anim. Sci. Pap. Rep., 30: 219-229.

Hanuš O., Frelich J., Janů L., Macek A., Zajíčková I., Genčurová V., Jedels ká R. (2007). Impact of different milk yields of cows on milk quality in Bohemian spotted cattle. Acta Vet. Brno, 76: 563-571. 
Hanuš O., Frelich J., Tomáška M., Vyletělová M., Genčurová V., Kučera J., Třináctý J. (2010 a). The analysis of relationships between chemical composition, physical, technological and health indicators and freezing point in raw cow milk. Czech J. Anim. Sci., 55: 11-29.

H a nu š O., S a m k ová E., Š pi čk a J., S ojk ová K., H a nušová K., K o p e c T., Vyletělo vá M., J e d e lská R. (2010 b). Relationship between concentration of health important groups of fatty acids and components and technological properties in cow milk. Acta Univ. Agric. Silvic. Mendel. Brun., 58: 137-154.

H a nu š O., K u č e r a J., Yong T., Chlád e k G., Holás e k R., Tř ináctý J., G e n ču rová V., S o j k ová K. (2011). Effect of sires on wide scale of milk indicators in first calving Czech Fleckvieh cows. Archiv. Tierzucht, 54: 36-50.

Hanuš O., H a nušová K., Vyle tělová M., K o p e c K., J a n ů L., K o pe c ký J. (2012). Selected abiotic factors that influence raw cow milk freezing point depression. Acta Vet. Brno, 81: 49-055.

He ck J.M.L., van Valen berg H.J.F., D ijkstra J., van Hooijdonk A.C.M. (2009). Seasonal variation in the Dutch bovine raw milk composition. J. Dairy Sci., 92: 4745-4755.

I konen T., Morri A., Tyris evä A.-M., Ruottinen O., Oja la M. (2004). Genetic and phenotypic correlations between milk coagulation properties, milk production traits, somatic cell count, casein content and pH of milk. J. Dairy Sci., 87: 458-467.

J a n ů L., Hanuš O., Fre li ch J., Ma c ek A., Zajíčková I., Genčurová V., Jedelská R. (2007 a). Influences of different milk yields of Holstein cows on milk quality indicators in the Czech Republic. Acta Vet. Brno, 76: 553-561.

J a n ů L., H a n uš O., M a c e k A., Z a jí č k ová I., G e n č u rová V., K o p e cký J. (2007 b). Fatty acids and mineral elements in bulk milk of Holstein and Czech Spotted cattle according to feeding season. Folia Veterinaria, 51: 19-25.

J e n s e n R.G. (2002). Invited review: The composition of bovine milk lipids: January 1995 to December 2000. J. Dairy Sci., 85: 295-350.

J õ u d u I., H e n n o M., K a a r t T., P ü s s a T., Kär t O. (2008). The effect of milk protein contents on the rennet coagulation properties of milk from individual dairy cows. Int. Dairy J., 18: 964-967.

K o lv e r E.S., M u 11 e r L.D. (1998). Performance and nutrient intake of high producing Holstein cows consuming pasture or a total mixed ration. J. Dairy Sci., 81: 1403-1411.

Kri ščiuna it e T., S tu lova I., Ta iv o s a lo A., L a h t T.-M., Vilu R. (2012). Composition and renneting properties of raw bulk milk in Estonia. Int. Dairy J., 23: 45-52.

Larsen M.K., Nielsen J.H., Butler G., Leifert C., Slots T., Kristiansen G.H., Gustafs s on A.H. (2010). Milk quality as affected by feeding regimens in a country with climatic variation. J. Dairy Sci., 93: 2863-2873.

Lindmark-Måns s o n H., F ondén R., P et ter s s o n H.E. (2003). Composition of Swedish dairy milk. Int. Dairy J., 13: 409-425.

Litwinczuk Z., Król J., Brodziak A., B arłowska J. (2011). Changes of protein content and its fractions in bovine milk from different breeds subject to somatic cell count. J. Dairy Sci., 94: 684-691.

Mal a c arne M., S u m mer A., Fos s a E., Formaggioni P., Frances chi P., P ecorari M., Mariani P. (2006). Composition, coagulation properties and Parmigiano-Reggiano cheese yield of Italian Brown and Italian Friesian herd milks. J. Dairy Res., 73: 171-177.

Meloun M., Militký J. (1994). Statistical processing of experimental data. (in Czech) Plus spol. s r.o. pp. 840 .

Politis I., Ng-Kw a i - H a n g K.F. (1988). Effect of somatic cell counts and milk composition on the coagulating properties of milk. J. Dairy Sci., 71: 1740-1746.

R oy B., Brahma B., Ghosh S., Pankaj P.K., Mandal G. (2011). Evaluation of milk urea concentration as useful indicator for dairy herd management: A review. Asian J. Anim. Vet. Adv., 6: $11-19$.

S a m k ová E., P e š e k M., Š p i č k a J., P e li ká n ová T., H a n u š O. (2009). The effect of feeding diets markedly differing in the proportion of grass and maize silages on bovine milk fat composition. Czech J. Anim. Sci., 54: 93-100.

S chennink A., S to o p W.M., Vis ker M.H.P.W., He ck J.M.L., B ovenhuis H., P o e 1 J.J., 
Valenberg H.J.F., Arendonk J.A.M. (2007). DGAT1 underlies large genetic variation in milk-fat composition of dairy cows. Anim. Genet., 38: 467-473.

S c hön feld t H.C., H a 11 N.G., S m it L.E. (2012). The need for country specific composition data on milk. Food Res. Inter., 47: 207-209.

Summer A., Formaggioni P., Tos i F., Foss a E., Mariani P. (1999). Effects of the hothumid climate on rennet-coagulation properties of milk produced during summer of 1998 and relationship with the housing systems in the rearing of Italian Friesian cows. Ann. Fac. Med. Vet. Univ. Parma., 19: 167-179.

Summer A., Malacarne M., Martuzzi F., Mariani P. (2002). Structural and fuctional characteristics of Modenese cow milk in Parmigiano-Reggiano cheese production. Ann. Fac. Med. Vet. Univ. Parma, 22: 163-174.

Ve e rkamp R.F., Ka a l L., de Haas Y., Oldham J.D. (2013). Breeding for robust cows that produce healthier milk: RobustMilk. Adv. in Anim. Biosci., 4: 594-599.

White S.L., Bertrand J.A., Wade M.R., Washburn S.P., Green Jr.J.T., Jenkins T.C. (2001). Comparison of fatty acid content of milk from Jersey and Holstein cows consuming pasture or a total mixed ration. J. Dairy Sci., 84: 2295-2301.

Wolfová M., Wolf J., K vapilík J., Kica J. (2007). Selection for profit in cattle: I. Economic weights for purebred dairy cattle in the Czech Republic. J. Dairy Sci., 90: 2442-2455.

Z a va di lová L., Wolf J., Š tí p k o vá M., Ně m c ová E., J a m ro zi k J. (2011). Genetic parameters for somatic cell score in the first three lactations of Czech Holstein and Fleckvieh breeds using a random regression model. Czech J. Anim. Sci., 56: 251-260.

Received: 11 VIII 2013

Accepted: 6 III 2014 